\title{
Naar een informatiesysteem onderwijs-arbeidsmarkt. Onderzoekprogramma 1989/1990
}

Citation for published version (APA):

Researchcentrum voor Onderwijs en Arbeidsmarkt, ROA. (1989). Naar een informatiesysteem onderwijsarbeidsmarkt. Onderzoekprogramma 1989/1990. Researchcentrum voor Onderwijs en Arbeidsmarkt, Faculteit der Economische Wetenschappen. ROA Reports No. 001

https://doi.org/10.26481/umarep.1989001

Document status and date:

Published: 01/01/1989

DOI:

10.26481/umarep.1989001

Document Version:

Publisher's PDF, also known as Version of record

\section{Please check the document version of this publication:}

- A submitted manuscript is the version of the article upon submission and before peer-review. There can be important differences between the submitted version and the official published version of record.

People interested in the research are advised to contact the author for the final version of the publication, or visit the DOI to the publisher's website.

- The final author version and the galley proof are versions of the publication after peer review.

- The final published version features the final layout of the paper including the volume, issue and page numbers.

Link to publication

\footnotetext{
General rights rights.

- You may freely distribute the URL identifying the publication in the public portal. please follow below link for the End User Agreement:

www.umlib.nl/taverne-license

Take down policy

If you believe that this document breaches copyright please contact us at:

repository@maastrichtuniversity.nl

providing details and we will investigate your claim.
}

Copyright and moral rights for the publications made accessible in the public portal are retained by the authors and/or other copyright owners and it is a condition of accessing publications that users recognise and abide by the legal requirements associated with these

- Users may download and print one copy of any publication from the public portal for the purpose of private study or research.

- You may not further distribute the material or use it for any profit-making activity or commercial gain

If the publication is distributed under the terms of Article $25 \mathrm{fa}$ of the Dutch Copyright Act, indicated by the "Taverne" license above, 
NAAR EEN INFORMATIESYSTEEM ONDERWIJS-ARBEIDSMARKT

- onderzoekprogramma 1989/1990 -

ROA-R-1989/1

RESEARCHCENTRUM VOOR ONDERWIJS EN ARBEIDSMARKT

Faculteit der Economische Wetenschappen

Rijksuniversiteit Limburg

Maastricht, juni 1989 
INHOUDSOPGAVE

Bladzijde

VOORWOORD

1. INLEIDING

2. DE POSITIE VAN HET ROA

4

3. HET INFORMATIESYSTEEM ONDERWIJS-ARBEIDSMARKT

8

4. HET ONDERZOEKPROGRAMMA 13

4.1. Inleiding 13

4.2. Voortgang van het programma 1988/1989 13

4.3. Het programma 1989/1990 23

BIJLAGE 1: Publikaties/Publications ROA 28

BIJLAGE 2: Personele samenstelling ROA 31

BIJLAGE 3: Samenstelling begeleidingscommissie van de meerjarige opdracht van het Ministerie van Onderwijs en Wetenschappen 
VOORWOORD

Dit programmeringsrapport van het Researchcentrum voor Onderwijs en Arbeidsmarkt (ROA) is samengesteld in het kader van een meerjarige onderzoekopdracht van het Ministerie van Onderwijs en Wetenschappen1. Deze opdracht houdt in het ontwikkelen van een informatiesysteem dat de (toekomstige) ontwikkelingen op de arbeidsmarkt weergeeft en de daarvan afgeleide eisen voor het onderwijs tot uitdrukking brengt. Het te ontwikkelen systeem zou bruikbaar moeten zijn voor de studie- en beroepskeuzevoorlichting in het voortgezet en het hoger onderwijs.

Voor de uitvoering van bovengenoemde opdracht is een programma van activiteiten ontwikkeld dat elk jaar wordt aangevuld en bijgesteld. Het programma betreft de geplande werkzaamheden voor een jaarlijks opschuivende periode van twee jaar. Inmiddels zijn twee programma's verschenen. Het eerste programma had betrekking op de periode 1987/1988 en het tweede op de periode $1988 / 1989^{2}$. Het voorliggende, derde, programmeringsrapport betreft de periode $1989 / 1990$.

Naast de onderzoekopdracht voor het ontwikkelen van een informatiesysteem onderwijs-arbeidsmarkt, worden door het ROA diverse onderzoekopdrachten uitgevoerd op nauw verwante gebieden. Hier moeten in het bijzonder worden genoemd de bijdrage van het ROA aan de arbeidsmarktmodule van het geautomatiseerde studie- en beroepskeuzesysteem I-See!, alsmede het onderzoek op het terrein van de ontwikkeling van methodieken voor het monitoren van de arbeidsmarktpositie van afgestudeerden van de diverse delen van het onderwijs. Voor een overzicht van de op basis van deze onderzoekopdrachten samengestelde publikaties wordt verwezen naar bijlage 1 bij dit rapport.

$\mathrm{Na}$ het verschijnen van het vorige programmeringsrapport is het aantal medewerkers van het ROA toegenomen van twaalf tot negentien. Ter informatie is in bijlage 2 de huidige personele bezetting van het ROA weergegeven.

1. Zie voor meer informatie over het ROA en de opdracht van het Ministerie van Onderwijs en Wetenschappen : Heijke, Het Researchcentrum voor Onderwijs en Arbeidsmarkt, ROA-R-1986/1, Maastricht.

2. Naar een informatiesysteem onderwijs-arbeidsmarkt, onderzoekprogramma 1987/1988, ROA-R-1987/2, Maastricht, en Naar een informatiesysteem onderwijs-arbeidsmarkt, onderzoekprogramma 1988/1989, ROA-R-1988/1, Maastricht. 
In bijlage 3 wordt een overzicht gegeven van de huidige samenstelling van de begeleidingscommissie van de meerjarige onderzoekopdracht van het Ministerie van Onderwijs en Wetenschappen voor de ontwikkeling van het informatiesysteem onderwijs-arbeidsmarkt.

Prof.dr.J.A.M. Heijke

directeur 


\section{INLEIDING}

Medio 1986 verleende het Ministerie van Onderwijs en Wetenschappen de opdracht aan het Researchcentrum voor Onderwijs en Arbeidsmarkt (ROA) voor de uitvoering van het project "onderwijs en arbeidsmarkt". Met dit meerjarige project werd beoogd te voorzien in de behoefte aan een instelling die zich op permanente basis bezig houdt met analyses en prognoses van de ontwikkelingen op de onderwijsmarkt en de arbeidsmarkt waarbij:

- beide ontwikkelingen met elkaar in verband worden gebracht;

- getracht wordt het gehele onderwijs en de totale arbeidsmarkt te bestrijken;

- zodanige differentiaties in de gegevens worden aangebracht dat een optimale aansluiting wordt verkregen met de meer kwalitatieve aspecten van de relatie onderwijs-arbeidsmarkt;

- naast het uitvoeren van toegepast onderzoek met name aandacht wordt besteed aan de theoretische onderbouwing daarvan.

In het rapport dat ten grondslag ligt aan het project onderwijs en arbeidsmarkt werden negen thema's genoemd die het werkterrein van het project meer specifiek afbakenen ${ }^{3}$. Uit deze thema's werd een voorlopige keuze gemaakt van vijf onderzoekthema's, waarvan het eerste thema de hoogste prioriteit werd gegeven. De vijf gekozen thema's zijn:

1. De ontwikkeling van de werkgelegenheid naar bedrijfstak, beroep (of functiecategorie) en vereiste kwalificaties, zoals bepaald door de economische ontwikkeling, de ontwikkeling van proces- en produkttechnologieën en bedrijfsorganisatorische veranderingen.

2. De belangstelling, de toe-, door- en uitstroom van leerlingen in regureguliere en bedrijfs(interne) (beroeps)opleidingen, zoals deze mede zijn bepaald door de demografische ontwikkeling, de schoolprestaties, de sociale achtergrond en de verwachtingen ten aanzien van de latere mogelijkheden op de arbeidsmarkt.

3. De discrepanties tussen vraag en aanbod op de arbeidsmarkt, naar kwalificatieniveau en -richting, alsmede de aard, werking en effectiviteit van de coördinatiemechanismen welke vraag en aanbod op de onderscheiden deelmarkten dichter bij elkaar kunnen brengen.

3. Heijke, Het Researchcentrum voor Onderwijs en Arbeidsmarkt, ROA-R-1986/1, Maastricht, blz. 12 e.v. 
4. De ontwikkeling van adequate datasystemen en -bronnen teneinde het onderzoek naar bovengenoemde thema's te kunnen uitvoeren.

5. De ontwikkeling van adequate classificatiesystemen zodat de via het onderzoek verschafte informatie op elkaar kan worden aangesloten, alsmede op de inrichting van het (beroeps)onderwijs en de ontwikkelde leerprogramma's.

In de opdrachtverlening van het project onderwijs en arbeidsmarkt werd gesteld dat het ROA in aansluiting op de genoemde thema's in ieder geval een informatiesysteem onderwijs-arbeidsmarkt zou moeten ontwikkelen. Dit systeem zou de toekomstige ontwikkelingen op de arbeidsmarkt moeten kunnen weergeven en de hieruit af te leiden eisen voor het onderwijs tot uitdrukking brengen. De door het systeem te verschaffen gegevens zouden bruikbaar moeten zijn voor de studie- en beroepskeuzevoorlichting aan leerlingen en studenten in het voortgezet- en het hoger onderwijs. Daarnaast zou het informatiesysteem kunnen bijdragen aan een verbetering van de capaciteitsplanning in het onderwijs en de benutting van de investeringen in kennis en vaardigheden van de bevolking ter versterking van het economisch potentieel.

In de jaarlijks uit te brengen programmeringsrapporten van het ROA wordt de opzet van het informatiesysteem telkens verder uitgewerkt aan de hand van de op dat moment bereikte onderzoekresultaten. Deze programmeringsrapporten bevatten tevens een programma van de onderzoekactiviteiten van het ROA. De onderzoeken met betrekking tot de verdere ontwikkeling van het informatiesysteem staan daarbij centraal. Het programma beslaat een elk jaar opschuivende periode van twee jaar waarbij voor het tweede jaar slechts een voorlopige indicatie van het onderzoekprogramma wordt gegeven. Het onderhavige rapport vormt het derde programmeringsrapport en heeft betrekking op de periode $1989 / 1990^{4}$.

Het nieuwe programmeringsrapport is op dezelfde wijze opgezet als het vorige. In hoofdstuk 2 wordt de positie van het ROA geschetst, zoals deze is gelegen tussen aan de ene kant de instellingen die statistische basisgegevens en -prognoses genereren en aan de andere kant de gebruikers van de

4. De reeds eerder verschenen programmeringsrapporten zijn: Naar een informatiesysteem onderwijs-arbeidsmarkt, onderzoekprogramma 1987/1988, ROAR-1987/2, Maastricht, en Naar een informatiesysteem onderwijs-arbeidsmarkt, onderzoekprogramma 1988/1989, ROA-R-1988/1, Maastricht. 
door het ROA te verschaffen informatie over de situatie op de middellange termijn in het onderwijs en op de arbeidsmarkt. In hoofdstuk 3 wordt een beeld geschetst van de huidige versie van het ontwikkelde informatiesysteem onderwijs-arbeidsmarkt. In hoofdstuk 4 wordt achtereenvolgens ingegaan op de voortgang van het programma 1988/1989 en het geplande activiteitenprogramma voor de periode $1989 / 1990$. 


\section{DE POSITIE VAN HET ROA}

De positie van het ROA kan worden toegelicht aan de hand van schema 1 . Het bovenste deel van het schema heeft betrekking op de gegevens waarop het ROAinformatiesysteem is gebaseerd. Een belangrijke basis wordt gevormd door de statistische gegevens van het Centraal Bureau voor de Statistiek (CBS) over de aantallen werkenden naar beroep, opleiding, leeftijd en arbeidsduur en over de aantallen leerlingen en studenten in het onderwijs. Met behulp van deze gegevens worden de modellen geschat waarmee de ontwikkelingen op de arbeidsmarkt en die in het onderwijs voor de toekomst worden geprognosticeerd. Uit deze gegevens worden ook de indicatoren berekend die een beeld geven van de werkgelegenheidsrisico's die aan het uitoefenen van de verschillende beroepen en functies zijn verbonden.

Er wordt getracht, naast het CBS, andere bronnen van statistische gegevens aan te boren, die een nauwkeuriger beeld geven van bepaalde onderdelen van de arbeidsmarkt of het onderwijs. Er wordt, deels in samenwerking met anderen, gewerkt aan het beschikbaar maken van gegevens over de uitstroom uit het onderwijs, met name de bestemming van schoolverlaters en afgestudeerden op de arbeidsmarkt. Ook wordt gedacht aan het genereren van gegevens over de werkgelegenheid in diverse bedrijfstakken en regio's. Omdat het ROA bij het beschikbaar maken van deze gegevens een actieve rol speelt of zou kunnen spelen, zijn de desbetreffende pijlen in het schema in twee richtingen getrokken.

Een belangrijk uitgangspunt voor de prognoses van de ontwikkelingen op de arbeidsmarkt wordt gevormd door de toekomstverkenningen van het Centraal $P l a n b u r e a u(C P B)$. Het betreft hier met name de middellange-termijnprognoses van de macro-economische ontwikkeling en de werkgelegenheid naar bedrijfstak. Daarnaast wordt gebruik gemaakt van middellange-termijnprognoses van de uitstroom uit het onderwijs naar opleidingscategorie. Deze prognoses zijn afkomstig van het CPB (SKILL), de Taakgroep Studentenramingen (WORSA en RHOBOS) en van het ROA zelf. Ook ten aanzien van de prognosegegevens wordt getracht bronnen aan te boren, die een beter en meer gedifferentieerd beeld geven van bepaalde onderdelen van de arbeidsmarkt of het onderwijs. Er wordt hier met name gedacht aan prognoses op het niveau van het beroepsdomein van bepaalde opleidingscategorieën. Het is denkbaar dat het ROA in de toekomst actief wordt betrokken bij het opstellen van dergelijke meer gedifferentieerde prognoses. 
Het is overigens van belang op te merken, dat er momenteel naar gestreefd wordt om de prognose-activiteiten op het terrein van het onderwijs en de arbeidsmarkt zo goed mogelijk te coördineren. Het platform dat hiervoor in het leven is geroepen is de interdepartementale commissie Onderwijs-Arbeidsmarkt Prognoses (OAP). Het ROA participeert in enkele werkgroepen van deze commissie.

Het informatiesysteem onderwijs-arbeidsmarkt wordt ontwikkeld op basis van toegepast wetenschappelijk onderzoek. Door de inpassing van het ROA in de economische faculteit van de Rijksuniversiteit Limburg wordt bevorderd, dat zo veel mogelijk profijt kan worden getrokken van de resultaten van onderzoek van een meer fundamenteel karakter. Het ROA probeert in aansluiting hierop ook het fundamentele onderzoek binnen de economische faculteit te stimuleren in een richting welke te zijner tijd vruchten zou kunnen afwerpen voor het informatiesysteem onderwijs-arbeidsmarkt.

In het onderste gedeelte van schema 1 is aangegeven welke informatie het systeem oplevert, in wat voor vorm deze informatie is gegoten en ten behoeve van welke beleidsvelden de informatie zou kunnen worden benut. Er zijn daarbij drie soorten informatie onderscheiden: historische data, prognosegegevens en overige indicatoren met betrekking tot de aansluiting onderwijsarbeidsmarkt. De verschafte informatie wordt verstrekt zowel in de vorm van geautomatiseerde gegevensbestanden als in de vorm van onderzoekrapporten, werkdocumenten en (overdrukken van) artikelen. Een geautomatiseerd gegevensbestand zal vooralsnog alleen te raadplegen zijn via het in ontwikkeling zijnde geautomatiseerde school- en beroepskeuzesysteem I-See!, dat overigens meer modules dan alleen de arbeidsmarktmodule omvat. De uitgebrachte rapporten en nota's zijn daarentegen direct verkrijgbaar bij het ROA. Voor een volledig overzicht van de tot nu toe verschenen publikaties wordt verwezen naar bijlage 1 .

De verschafte informatie richt zich thans primair op de studie- en beroepskeuzevoorlichting. De desbetreffende gegevens bieden echter ook goede aanknopingspunten voor de planning van leerlingencapaciteiten en curricula in het onderwijs, het economische structuur -en technologiebeleid, de om-, heren bijscholing van werkenden en werklozen en de personeelsplanning van bedrijven en instellingen. De potentiële afnemers van de informatie worden gevormd door de instanties die op de genoemde beleidsvelden actief zijn. In 
het schema worden de volgende instanties genoemd: schooldecanen, studie- en beroepskeuze-adviseurs, onderwijsinstellingen, ministeries, arbeidsbureaus en het bedrijfsleven. 


\section{HET INFORMATIESYSTEEM ONDERWIJS-ARBEIDSMARKT}

In 1987 kwam de eerste versie van het informatiesysteem onderwijs-arbeidsmarkt gereed ${ }^{5}$. In deze versie werden gegevens verstrekt op basis van een indeling van de arbeidsmarkt naar 23 bedrijfstakken, 82 beroepsgroepen en 13 clusters van universitaire studierichtingen. Het informatiesysteem omvatte de volgende gegevens:

- Historische data. Ten aanzien van beroepen werden gegevens verstrekt over het aantal werkenden, de leeftijdsopbouw, de genoten opleidingen en de bedrijfsklassen waarin men werkzaam is. De gegevens over opleidingen betroffen het aantal werkenden, de beroepsklassen waarin men werkzaam is en de werkloosheid.

- Indicatoren. Voor beroepen werden indicatoren gegeven van de vervangingsbehoefte, de absorptie van jongeren, de branchespreiding en de conjunctuurgevoeligheid. Voor opleidingen werd alleen een indicator gegeven van de spreiding over beroepen.

- Prognoses. De prognoses hadden betrekking op de periode 1985-1992. De prognoses van beroepen leverden gegevens op over de werkgelegenheidsontwikkeling, de vervangingsvraag, de hieruit resulterende vraag naar nieuwkomers en over de vraag naar onderwijsverlaters. De prognoses voor (universitaire) opleidingen resulteerden in gegevens over de werkgelegenheidsontwikkeling, de vervangingsvraag, de hieruit resulterende vraag naar nieuwkomers, de instroom van afgestudeerden en de confrontatie van de vraag naar nieuwkomers en de instroom van afgestudeerden.

In 1988 werden deze gegevens aangevuld, geactualiseerd en waar nodig gecorrigeerd6. In 1989 zal een geheel nieuwe versie van het informatiesysteem gereedkomen. Hierbij zal het aantal onderscheiden opleidingscategorieën aan-

5. De Grip, Heijke, Dekker, Groot en Vos, De arbeidsmarktperspectieven van studierichtingen in het wetenschappelijk onderwijs 1992, Arbeidsmarktmodule I-SEE project, ROA-R-1987/3, Maastricht. Zie ook: De Grip, Heijke, Dekker en Groot, De arbeidsmarkt naar beroep in 1992 en de positie van academici daarbinnen, ROA-W-1987/1, Maastricht, en van dezelfde auteurs, De arbeidsmarkt naar beroep in 1992, en Arbeidsmarktperspectieven van universitaire studierichtingen, in: Economisch Statistische Berichten, respectievelijk 29 juni 1988, blz. 617-622 en 6 juli 1988, blz. 628-631, 636.

6. De Grip, Heijke, Van Dam, Dekker en Wieling, Aanvulling arbeidsmarktmodule I-SEE project (wetenschappelijk onderwijs), ROA-R-1988/2, Maastricht. 
zienlijk worden vergroot. De 13 clusters van universitaire studierichtingen worden uitgebreid tot 60 opleidingscategorieën, die het gehele reguliere voortgezet en hoger onderwijs omvatten. Helaas is het vooralsnog niet mogelijk de prognosetermijn met twee jaar te verlengen tot 1994, wegens het ontbreken van recente arbeidsmarktinformatie over beroepen en opleidingen uit de Enquête Beroepsbevolking (EBB), de opvolger van de Arbeidskrachtentelling (AKT).

In schema 2 is aangegeven hoe het informatiesysteem onderwijs-arbeidsmarkt dat in 1989 zal gereedkomen er uit zal zien. De belangrijkste verschillen met de vorige versie van het systeem ${ }^{7}$ zijn dat er is getracht rekening te houden met enkele factoren die voor de arbeidsmarkt van grote betekenis kunnen zijn, maar in de vorige versie nog niet expliciet werden onderscheiden. Deze factoren zijn: de stand van de techniek, de conjunctuurfase en de verdringing op de arbeidsmarkt.

Het informatiesysteem dat nu wordt ontwikkeld kan aan de hand van schema 2 als volgt worden toegelicht. Het bovenste deel van het schema heeft betrekking op de belangrijkste veronderstellingen en extern opgestelde prognoses die ten grondslag liggen aan de arbeidsmarktprognoses van het ROA. Daaronder wordt de globale structuur van het systeem weergegeven. Het systeem is opgebouwd in drie lagen. De bovenste laag betreft de bedrijfstakgegevens, de middelste laag heeft betrekking op het beroependeel van het informatiesysteem en de onderste laag geeft het opleidingendeel weer.

De veronderstellingen en prognoses die de uitgangspunten vormen voor de arbeidsmarktprognoses van het ROA worden ontleend aan het CPB. De desbetreffende gegevens zijn:

- de ontwikkeling per bedrijfstak van de investeringen, de toegevoegde waarde, het arbeidsvolume, de arbeidsduur en de mate van deeltijdarbeid;

- de demografische ontwikkeling en de daaruit afgeleide ontwikkeling van de leerlingenstromen door en uit het onderwijs en de opleidingsstructuur van de potentiële beroepsbevolking;

- de participatiegraad van de bevolking.

Uit de CPB-prognoses van het arbeidsvolume per bedrijfstak wordt door het ROA voor elke bedrijfstak de werkgelegenheid in aantallen personen naar

7. Zie het vorige onderzoekprogramma, ROA-R-1988/1, blz. 10-11. 
beroep afgeleid. Hierbij wordt gebruik gemaakt van modellen waarin expliciet wordt rekening gehouden met de invloed van de technologie en de conjunctuur op de beroepenstructuur van de werkgelegenheid per bedrijfstak ${ }^{8}$. De technologie wordt gemeten via de variabelen kapitaalintensiteit en het aandeel automatiseringspersoneel per bedrijfstak; de conjunctuur wordt gemeten via de bezettingsgraad van de produktiecapaciteit per bedrijfstak. Deze benadering vormt een belangrijke stap vooruit vergeleken met de eerste versie van het informatiesysteem, waarbij de ontwikkeling van de desbetreffende werkgelegenheidsaandelen werd gerelateerd aan het verloop van de tijd of aan de werkgelegenheidsontwikkeling per bedrijfstak.

Ook de prognoses van de werkgelegenheid naar opleiding worden op een andere manier opgezet. In de vorige versie van het informatiesysteem werd de werkgelegenheid naar opleiding afgeleid van de totale werkgelegenheid naar beroep. Hierbij werden de opleidingsaandelen per beroep, analoog aan bovengenoemde beroepenmodellen, gerelateerd aan het verloop van de tijd of aan de werkgelegenheidsontwikkeling per beroep. In de nieuwe opzet wordt een aanzienlijk meer verfijnde aanpak gevolgd. De opleidingenstructuur van beroepen wordt nu afzonderlijk per bedrijfstak bepaald. Eerst wordt het opleidingsniveau van het beroep in de bedrijfstak bepaald, rekeninghoudende met zowel de mogelijkheid van "upgrading" of "downgrading" door de technische ontwikkeling als de mogelijkheid dat lagere door hogere opleidingsniveaus worden verdrongen op grond van de ontwikkeling van de relatieve aandelen van deze niveaus in de potentiële beroepsbevolking. Daarna wordt voor elk opleidingsniveau binnen een beroep in een bedrijfstak de werkgelegenheid naar opleidingsrichting bepaald. Wat het laatste betreft wordt nog onderzocht of hiervoor verklarende factoren kunnen worden gevonden, of dat met een eenvoudige trendextrapolatie moet worden volstaan.

De benadering van de vervangingsvraag naar beroep en naar opleiding is ongewijzigd gebleven. Op basis van onder meer de geprognosticeerde participatiegraad van de verschillende leeftijdscohorten en de leeftijdenstructuur van het aantal werkzame personen naar beroep in het basisjaar van de prognoses, wordt een schatting gemaakt van de toekomstige vervangingsvraag naar beroep over de prognoseperiode. Dit opgeteld bij de geprognosticeerde toe- of afname van het aantal werkzame personen naar beroep levert een raming op van

8. Dekker, De Grip en Heijke, Een verkenning van de beroepenstructuur van bedrijfstakken, ROA-W-1988/2, Maastricht. 
de totale vraag naar nieuwkomers per beroep over de prognoseperiode. De vervangingsvraag naar opleiding wordt geprognosticeerd op basis van het vertrek van ouderen uit beroepen en de opleidingenstructuur van deze beroepen. Door optelling van vervanging en uitbreiding per opleiding wordt de totale vraag naar nieuwkomers per opleiding over de prognoseperiode verkregen.

In het beroependeel van het schema staat aangegeven dat de geprognosticeerde vraagontwikkeling naar beroep, samen met de berekende indicatoren van de conjunctuurgevoeligheid en de branchespreiding van de verschillende beroepen, een algehele typering geven van het werkgelegenheidsperspectief naar beroep.

In het opleidingendeel van het schema is aangegeven dat de geprognosticeerde vraag naar nieuwkomers per opleiding wordt geconfronteerd met de geprognosticeerde uitstroom van afgestudeerden per opleiding. De uitstroomprognoses zijn ontleend aan de Taakgroep Studentenramingen (voor het hoger onderwijs), het CPB (voor de lagere niveaus) en het ROA zelf voor de niet door het CPB onderscheiden differentiaties en de niet door het CPB of de Taakgroep Studentenramingen onderscheiden opleidingen. De discrepanties die resulteren uit de confrontatie van de vraag naar nieuwkomers met de uitstroom uit het onderwijs en de berekende indicator van de mate van spreiding van de afgestudeerden in een bepaalde opleiding over de beroepen, geven een algehele typering van het arbeidsmarktperspectief van de desbetreffende opleiding. 


\section{HET ONDERZOEKPROGRAMMA}

\subsection{Inleiding}

Zoals in het eerste hoofdstuk reeds werd opgemerkt, dekt het onderzoekprogramma een jaarlijks opschuivende periode van twee jaar, waarbij het programma voor het tweede jaar slechts als indicatief moet worden beschouwd. Het programma voor 1990 zal dus pas in het programmeringsrapport voor de periode 1990/1991 definitief worden ingevuld. De jaarlijkse bijstelling vindt plaats op basis van de voortgang van het onderzoek en de ontwikkeling van nieuwe onderzoekplannen.

Het programma bestaat uit twee delen. Deel A heeft betrekking op het onderzoek dat wordt uitgevoerd binnen het kader van de meerjarige onderzoekopdracht van het Ministerie van Onderwijs en Wetenschappen. Deel B betreft een overzicht van het buiten deze opdracht lopende onderzoek. Omdat deze "B-projecten" binnen andere kaders worden uitgevoerd zullen zij niet altijd tot resultaten leiden die rechtstreeks inpasbaar zijn in het informatiesysteem onderwijs-arbeidsmarkt.

Evenals vorig jaar wordt het onderzoekprogramma besproken in twee stappen. Eerst wordt ingegaan op de voortgang van het oude programma 1988/1989. Hierbij zal worden aangegeven welke projecten zijn afgesloten, welke nog lopen, met welke projecten nog moet worden begonnen en welke nieuwe projecten aan het oude programma zullen worden toegevoegd. De tweede stap bij de ontwikkeling van het nieuwe programma bestaat uit het geven van een overzicht van het programma voor de periode 1989/1990.

\subsection{Voortgang van het programma $1988 / 1989$}

De onderzoekactiviteiten van het ROA kunnen ruwweg worden verdeeld naar activiteiten die zijn gericht op:

- de toepassing van het informatiesysteem onderwijs-arbeidsmarkt op de in schema 1 genoemde beleidsvelden;

- het ontwikkelen van nieuwe bronnen van statistische basisgegevens;

- de verdere ontwikkeling van de gebruikte prognosemodellen en arbeidsmarktindicatoren. 
Gebruik van het informatiesysteem

Een zeer belangrijke toepassingsmogelijkheid van het informatiesysteem onderwijs-arbeidsmarkt wordt gevormd door de bijdrage van het ROA aan het project $I$-See!. Dit project betreft de ontwikkeling van een gebruiksvriendelijk geautomatiseerd systeem voor de studie- en beroepskeuze. De naam ISee! staat voor Information System on Education and Employment. Door middel van dit systeem krijgen leerlingen en studenten langs menugestuurde wegen toegang tot een schat aan gegevens over opleidingen, met deze opleidingen te vervullen beroepen en de arbeidsmarktperspectieven van deze opleidingen en beroepen. In de pilotfase van het project werd een systeem ontwikkeld voor universitaire studierichtingen. Het ROA heeft hieraan een bijdrage geleverd met betrekking tot de arbeidsmarktgegevens ${ }^{9}$. I-See! zal, zoals gezegd, in de loop van 1989 worden verbreed tot alle opleidingen in het voorgezet en hoger onderwijs. De bijdrage van het ROA betreft opnieuw het berekenen en analyseren van de arbeidsmarktsituatie en -perspectieven van beroepen en opleidingen. Door het ROA zullen gegevens worden geleverd voor 60 opleidingscategorieën over de volle breedte van het onderwijs, en voor 82 beroepsklassen en 23 bedrijfstakken die de gehele arbeidsmarkt dekken (88/B2).

Er wordt naar gestreefd I-See! eind 1989 gereed te hebben. I-See! zal dan in exploitatie worden genomen door het Landelijk Dienstverlenend Centrum (LDC) i.o. Het LDC zal een onafhankelijke stichting vormen die is opgezet vanuit het Ministerie van Onderwijs en Wetenschappen en het (toekomstige) Centraal Bestuur voor de Arbeidsvoorziening.

Door participatie in het I-See! project is voldaan aan de door het Ministerie van Onderwijs en Wetenschappen aanvankelijk geuite wens om in samenwerking met anderen een handboek te ontwikkelen met gegevens over opleidingen, beroepen en arbeidsmarktperspectieven. Hierbij werd gedacht aan een publikatie zoals het Handbook of Occupational Outlook van het Bureau of Labor Statistics van het US Department of Labor. I-See! zal echter een aanzienlijk efficiëntere en rijkere gegevensbron kunnen vormen dan een dergelijk handboek.

9. Zie de reeds genoemde rapporten ROA-R-1987/3 en ROA-R-1988/2. 
Naast de toelevering van gegevens aan I-See! streeft het ROA ook naar een zelfstandige publikatie. Deze publikatie zal de vorm krijgen van een rapport dat toegankelijk is voor met name besturen en decanen van scholen, voor beleidsfunctionarissen bij de overheid en daaraan verwante instellingen en voor personeelsfunctionarissen bij zowel het bedrijfsleven als de overheid. Dit rapport zal de eerste versie vormen van een tweejaarlijks uit te brengen publikatie met gegevens over de middellange-termijnperspectieven van opleidingen op de arbeidsmarkt (89/A4).

De methodologische verantwoording van de arbeidsmarktprognoses en berekende indicatoren zal in deze rapporten globaal en beschrijvend van aard zijn. De uitgebreide wetenschappelijke verantwoording zal zoals voorheen voornamelijk plaatsvinden via de reeks ROA-werkdocumenten. De eerste versie van bovengenoemd rapport zal zijn gebaseerd op de resultaten van de uitvoering van het project "herschatting van de ontwikkelde modellen en opstelling van nieuwe middellange-termijnprognoses" (89/4) uit het onderzoekprogramma $1988 / 1989$.

In het vorige onderzoeksprogramma wordt tevens het project "evaluatie van de eerste ROA-prognose" (89/3) genoemd, alsmede het project "onderzoek onder (potentiële) afnemers naar de wenselijke aard en de geschikte vorm (produkten) van de gegevens uit het informatiesysteem" (88/9). Deze projecten zijn niet in uitvoering genomen. Door de versnelde ontwikkeling van het informatiesysteem vormt de eerste ROA-prognose, die wat het onderwijs betreft alleen op universitaire studies betrekking had, een reeds gepasseerd station. Een evaluatie van deze prognose is derhalve weinig zinvol. Een evaluatie van de prognose die thans over de volle breedte van het onderwijs wordt ontwikkeld kan tot meer bruikbare resultaten leiden. Ook een uitgebreid marktonderzoek naar de meest geschikte vorm van publikatie heeft door de koppeling aan I-See! geen zin meer.

De gebruiksmogelijkheden van het informatiesysteem onderwijs-arbeidsmarkt hangen in belangrijke mate af van de wijze waarop scholieren en studenten zich informeren over opleidings- en beroepsmogelijkheden, welke factoren zij daarbij in beschouwing nemen en hoe de verkregen informatie doorwerkt in de gemaakte gedragkeuzes. Door middel van een tweetal onderzoeken die in het kader van het stageprogramma "arbeidsmarktpositie van LTS-leerlingen" (88/B3) onder leerlingen en afgestudeerden van een lagere technische school 
zijn uitgevoerd, wordt hierin enig empirisch inzicht verkregen. Meer fundamenteel inzicht op dit punt kan worden verkregen uit het project "de betekenis van de aard en het tijdpatroon van de beschikbare arbeidsmarktinformatie voor de keuzen binnen het onderwijs en voor de allocatie op en de dynamiek van de arbeidsmarkt" (88/B4). Een eerste werkdocument over dit project is inmiddels verschenen 10 . Dit project is overigens niet alleen van belang voor het verkrijgen van inzicht in wat relevante factoren zijn voor de studie- en beroepskeuze, maar met name ook voor een beter inzicht in de mogelijke dynamische effecten van een verbeterde informatievoorziening over de arbeidsmarktperspectieven van opleidingen. Onder het A-deel van het programma voor 1989/1990 zijn enkele empirische verkenningen op dit terrein opgenomen (89/A7).

\section{Nieuwe databronnen}

Met de activiteiten die zijn gericht op het ontwikkelen van nieuwe databronnen, zijn belangrijke stappen vooruit gezet. In dit verband moet worden genoemd de projectcoördinatie van het pilot-project "Registratie Uitstroom en Bestemming van Schoolverlaters (RUBS)" (88/B6). Dit project heeft als doel het ontwikkelen van een systeem voor het registreren van de uitstroom van schoolverlaters, hun "eerste bestemming" op de arbeidsmarkt en de doorstroom naar vervolgonderwijs. Het systeem wordt gebaseerd op een jaarlijks te houden representatieve enquête onder zowel gediplomeerde als niet gediplomeerde schoolverlaters. De te verkrijgen gegevens zullen bruikbaar moeten zijn voor onder meer de studie- en beroepskeuzevoorlichting. Voor het ROA is dit project vooral van belang omdat het een voor analyse en prognose bruikbaar gegevensbestand kan opleveren, als aanvulling op de Arbeidskrachtentelling en de Enquête Beroepsbevolking, die weliswaar de gehele beroepsbevolking betreffen maar vanwege het steekproefkarakter onvoldoende differentiatie toelaten met betrekking tot de positie van de schoolverlaters.

De RUBS-enquête wordt uitgevoerd door een groot aantal Contactcentra Onderwijs-Arbeid (COA's). Het RION te Groningen verzorgt de ontwikkeling van het onderzoekinstrumentarium. In het project participeert tevens de Landelijke Commissie Studievoorlichting (LCAS) die een systematiek tracht te ontwik-

10. Borghans, Information and the choice for schooling, ROA-W-1989/1E, Maastricht. 
kelen waarmee met behulp van leerlingengegevens van individuele scholen de trendmatige ontwikkelingen in de onderwijsuitstroom kunnen worden aangegeven en geëxtrapoleerd. Het ROA is verantwoordelijk voor de landelijke projectcoördinatie. Begin 1990 zal een rapport over het project verschijnen warin de bereikte resultaten worden weergegeven en voorstellen worden gedaan voor de follow-up van het project, naar inhoud, vorm en mogelijke financieringsbronnen.

In aansluiting op dit onderzoekproject wordt door het ROA in enkele kleine projecten bepaalde delen van de RUBS-systematiek beproefd. Het gaat hier met name om de toepassing van een uniforme definiëring en classificatie van begrippen uit de schoolverlatersenquête die een koppeling aan CBS-databestanden mogelijk maken. De desbetreffende projecten zijn de stage-onderzoeken die worden uitgevoerd onder leerlingen en schoolverlaters bij een lagere technische school (88/B3) en een enquête-onderzoek onder afgestudeerden van het middelbaar beroepsonderwijs in Midden-Limburg (88/B7). In het laatstgenoemde onderzoek is ook geëxperimenteerd met een uitbreiding van de vragenlijst, gericht op het in beeld brengen van de kwalitatieve aansluitingsproblematiek tussen onderwijs en arbeidsmarkt.

Het RUBS project omvat in principe ook het hoger beroepsonderwijs, echter niet het wetenschappelijk onderwijs. Het ROA heeft evenwel van het Ministerie van Onderwijs en Wetenschappen de opdracht ontvangen voor een pilot-onderzoek gericht op het ontwikkelen van een systeem om de arbeidsmarkt van academici periodiek in kaart te brengen (te "monitoren") (88/B5). Dit monitoringsysteem zal zijn gebaseerd op een periodieke enquêtering van afgestudeerden en hun werkgevers. Het pilotonderzoek heeft betrekking op de arbeidsmarkt van de afgestudeerden van de faculteit der gezondheidswetenschappen van de Rijksuniversiteit Limburg. Het onderzoek zal binnen enkele maanden worden afgesloten. Er wordt gezocht naar een effectieve manier om de resultaten van dit onderzoek onder de aandacht van de universiteiten te brengen, bijvoorbeeld via het organiseren van een workshop. Inmiddels is van de Rijksuniversiteit Limburg de opdracht ontvangen het monitoringsysteem op te zetten voor de afgestudeerden van alle faculteiten van deze universiteit $(89 / B 1)$.

De projecten uit het onderzoekprogramma 1988/1989 "inventarisatie van instanties die prognoses opstellen" $(88 / 6)$ en "inventariseren van databestan- 
den" (88/7) hebben niet tot in het ROA-informatiesysteem inpasbare gegevens geleid. Over de situatie ten aanzien van de academici is een werkdocument samengeste1d11. Met betrekking tot het hoger beroepsonderwijs loopt nog een in samenwerking met de HBO-raad gehouden inventariserende enquête onder alle instellingen op dit terrein (89/A5). Na analyse van de resultaten zal ook hierover een werkdocument worden samengesteld.

De resultaten van deze inventarisaties bieden nuttige aanknopingspunten voor bovengenoemde projecten met betrekking tot het ontwikkelen van monitoringsystemen. Het vooralsnog ontbreken van bruikbare databestanden maakt het evenwel nog niet mogelijk de in het programma onderscheiden projecten "inpassing van prognosegegevens uit andere bronnen" (89/1) en "inpassing aanvullende databestanden" (89/A2) aan te vatten. Op dit punt is de hoop gevestigd op de resultaten van het RUBS-project en de implementatie van de bevindingen van de pilotstudie met betrekking tot de academici.

Het informatiesysteem onderwijs-arbeidsmarkt bevat vooralsnog alleen nationale gegevens. Voorzover deze gegevens een ondersteuning vormen voor studiekeuzes met betrekking tot het hoger onderwijs is het schetsen van een dergelijk nationaal beeld waarschijnlijk een adequate aanpak. Geschoolden op een lager niveau oriënteren zich echter vooral op de regionale arbeidsmarkt. Er zal daarom tijdens de nieuwe programmaperiode een verkenning worden verricht naar de mogelijkheden om op basis van het nationale informatiesysteem en aanvullende regionale basisgegevens ook informatie te verstrekken over de perspectieven van opleidingen op de regionale arbeidsmarkt (90/A2).

\section{Verdere ontwikkeling van het informatiesysteem}

De derde groep activiteiten uit het onderzoekprogramma betreft de verdere ontwikkeling van de gebruikte prognosemodellen en arbeidsmarktindicatoren.

Een belangrijk basisgegeven voor de prognosemodellen wordt gevormd door de arbeidsduur. De reden hiervan is dat in de door het ROA ontwikkelde modellen van de beroepenstructuur van sectoren een omrekening plaatsvindt van de werkgelegenheid (per bedrijfstak) in arbeidssvolume naar de werkgelegenheid (per beroep) in werkzame personen, waarbij de arbeidsduur de belangrijkste

11. Van Dam, De Grip en Heijke, Op zoek naar informatiebronnen over de arbe idmarktpositie van academici, ROA-W-1988/3, Maastricht. 
schakel vormt tussen het arbeidsvolume en het aantal werkzame personen. In het kader van het project "verklarend model voor het prognosticeren van de arbeidsduur "(88/A1) zijn schattingen gemaakt van de arbeidsduur naar beroep en sector. Met behulp van de verkregen gegevens is een model ontwikkeld waarmee de toekomstige arbeidsduur kan worden geprognosticeerd. Daarbij is met name de mate waarin in deeltijd wordt gewerkt relevant. Dit betekent dat een model moet worden ontwikkeld waarmee deze factor kan worden geprognosticeerd, om daaruit vervolgens de toekomstige mate van deeltijdarbeid te kunnen afleiden. Hoewel de onderzoekactiviteiten nog niet zijn afgerond, is wel al duidelijk geworden dat het percentage vrouwen in een beroep de belangrijkste verklarende factor vormt voor de mate warin in een beroep en/of bedrijfssector in deeltijd wordt gewerkt.

Het project "ontwikkeling en schatting van beroepenverdeelmodellen" (88/2) is afgesloten met een werkdocument ${ }^{12}$. De resultaten zullen worden toegepast in het kader van de ontwikkeling van I-See!. Na het beschikbaar komen van de gegevens over de arbeidsduur en de resultaten van de door het CBS gehouden Enquête Beroepsbevolking 1987 en/of 1988 zullen de beroepenverdeelmodellen opnieuw worden geschat en geactualiseerd (89/A4).

In het kader van het project "substitutieprocessen tussen opleidingscategorieën" (88/A4) worden modellen ontwikkeld voor het prognosticeren van de werkgelegenheid naar opleidingsniveau en -richting per beroep en sector. Hierbij wordt niet alleen de directe relatie tussen opleiding en beroep onderzocht, maar wordt ook nagegaan in hoeverre de stand van de techniek en de verdringing op de arbeidsmarkt tussen opleidingsniveaus hierbij een rol spelen. De eerste resultaten van dit project zullen worden toegepast in het kader van het I-See! project (88/B2). De afronding van het onderzoeksproject zal later plaatsvinden.

In het informatiesysteem onderwijs-arbeidsmarkt wordt een confrontatie gemaakt tussen de werkgelegenheid voor nieuwkomers op de arbeidsmarkt en de uitstroom uit het onderwijs. De beschikbare prognoses van de onderwijs-uitstroom zijn echter niet gedetailleerd genoeg, vooral ten aanzien van de lagere niveaus. Bovendien ontbreekt het deeltijdonderwijs en het niet-reguliere onderwijs. In het kader van het project I-See! worden deze ontbrekende gegevens door het ROA zelf geschat (88/B2). Het ziet er echter naar

12. Zie het reeds genoemde werkdocument ROA-W-1988/2. 
uit dat deze gegevens daarna verder zullen moeten worden aangevuld en de ontwikkelde onderwijsstroommodellen moeten worden verbeterd (89/A4).

De werkgelegenheid voor nieuwkomers is de resultante van de uitbreiding van de werkgelegenheid en de vervangingsbehoefte wegens doorstroming naar elders, pensionering enz. De vervangingsbehoefte is echter moeilijk te bepalen, omdat deze niet expliciet bekend is maar uit andere gegevens moet worden afgeleid. De tot nu toe gevolgde methode, die in een zeer kort tijdsbestek is ontwikkeld, heeft waarschijnlijk nog enkele tekortkomingen. Het is derhalve noodzakelijk de modellen waarmee de vervangingsbehoefte naar opleiding en naar beroep wordt geprognosticeerd nader te beoordelen en zo nodig en mogelijk te verbeteren (89/A4).

Bij de verklaring van de beroepenstructuur van sectoren en de opleidingenstructuur van beroepen spelen technologische factoren een rol. Dit is gebleken uit de gevonden relatie tussen de kapitaalintensiteit van de produktie en de beide structuurgrootheden. Het is echter de vraag of de gebruikte indicator voor de kapitaalintensiteit de betekenis van de technologische ontwikkeling in voldoende mate tot uitdrukking brengt. In het nieuwe programma is daarom een project opgenomen dat een inventarisatie betreft van indicatoren voor technologische veranderingen, waaronder alternatieve metingen van de kapitaalintensiteit (90/A3). In dit onderzoekproject zullen modellen worden ontwikkeld warin de relatie tussen deze indicatoren en de beroepenstructuur van sectoren en de opleidingenstructuur van beroepen tot uitdrukking wordt gebracht. In dit kader zullen ook de resultaten kunnen worden betrokken van het binnenkort afgeronde project "het traceren van de directe gevolgen van de technologische veranderingen in het bankwezen voor de werkgelegenheid, de beroepenstructuur en de opleidingsbehoefte" (88/B1).

In het kader van de ontwikkeling van het informatiesysteem onderwijs-arbeidsmarkt zijn twee indicatoren ontwikkeld die informatie geven over de werkgelegenheidsrisico's die aan bepaalde opleidingen en beroepen zijn verbonden. Deze indicatoren vormen een matstaf voor de spreiding van opleidingen over beroepen en van beroepen over bedrijfstakken en een maatstaf voor de conjunctuurgevoeligheid van bepaalde opleidingen en beroepen. De gedachte achter deze indicatoren is dat hoe groter de spreiding en hoe kleiner de conjunctuurgevoeligheid hoe groter de werkzekerheid is met de desbetreffende opleiding of in het desbetreffende beroep. In een werkdocu- 
ment, waarin de resultaten zijn weergegeven van project (88/3), zijn enkele nieuwe indicatoren ontwikkeld, bijvoorbeeld voor de verdringing tussen opleidingsniveaus, de substitutiemogelijkheden tussen opleidingen en de toeen uittredingsmobiliteit met betrekking tot beroepen13. Getracht zal worden enkele van deze indicatoren te kwantificeren en aan het informatiesysteem onderwijs-arbeidsmarkt toe te voegen (89/A6).

Het ligt bovendien voor de hand dit project uit te voeren in relatie met het project "inventarisatie van technologie-indicatoren met betrekking tot scholing en arbeid" (89/B2) dat in opdracht van het Ministerie van Economische Zaken wordt verricht. Bij het laatste project gaat het om de kwantificering van indicatoren die een beeld geven van de mate waarin het (gevolgde) onderwijs een goede matschappelijke voedingsbodem biedt voor de diffusie van technologische vernieuwingen. De internationale opzet van het laatste project biedt de mogelijkheid een vergelijking te maken met andere landen.

De indicator voor de uitwijkmogelijkheden voor opleidingen en beroepen op de arbeidsmarkt is ontwikkeld aan de hand van de uitwijkmogelijkheden zoals deze zich in het recente verleden hebben voorgedaan. De gerealiseerde mogelijkheden kunnen echter mede het resultaat zijn van de onder de druk van de arbeidsmarktsituatie onderkende en tot stand gekomen "matching" tussen opleidingen en beroepen. Hetzelfde geldt voor de functie- c.q. beroepenstructuur van bedrijfstakken. Door deze indicator te berekenen op basis van de opgestelde middellange-termijnprognoses wordt beter ingespeeld op de veranderende aansluitingsmogelijkheden tussen het onderwijs en de arbeidsmarkt (89/A6).

De modellen die in het kader van het informatiesysteem onderwijs-arbeidsmarkt zijn ontwikkeld hebben meestal het karakter van een verdeelmodel. Dit betekent dat het vertrekpunt wordt gevormd door reeds beschikbare prognoses van bepaalde aggregaten (bedrijfssectoren, beroepsklassen). De ontwikkelde modellen maken het dan mogelijk deze aggregaten te verdelen naar subcategorieën als opleidingen of beroepen. Door de grote mate van desagregatie van het informatiesysteem zijn veel cellen van de relatie opleiding, beroep en bedrijfstak niet gevuld. Dit geeft problemen bij de toepassing van de be-

13. De Grip en Heijke, Arbeidsmarktindicatoren: een inventarisatie, ROA-W1988/1, Maastricht. 
schikbare standaardtechnieken om de desbetreffende verdeelmodellen te schatten. Tot nu toe zijn hiervoor praktische oplossingen gevonden, die echter niet geheel bevredigend zijn, omdat onvoldoende rekening wordt gehouden met de onderlinge afhankelijkheid van de desbetreffende aandelen. In het nieuwe programma is daarom een literatuurstudie opgenomen naar schattingstechnieken voor verdeelmodellen, waarbij aan de onderlinge afhankelijkheid van de aandelen wordt recht gedaan en waarbij het probleem van de lege cellen wordt ondervangen (89/A8).

Bij de bespreking van de activiteiten met betrekking tot het gebruik van het informatiesysteem is opgemerkt dat een eerste versie zal worden uitgebracht van het elke twee jaar uit te brengen rapport met gegevens over de middellange-termijnperspectieven van opleidingen op de arbeidsmarkt. In aansluiting op dit voornemen is het van belang op te merken dat in het nieuwe programma de samenstelling van een afzonderlijke publikatie is opgenomen, waarin een wetenschappelijke verantwoording zal worden gegeven van de gevolgde werkwijze en de toegepaste modellen bij de bouw en de toepassing van het informatiesysteem onderwijs-arbeidsmarkt (89/A4). Deze publikatie zal deels een overzicht bevatten van de eerder uitgebrachte werkdocumenten. Er zal echter concreter worden aangegeven hoe de ontwikkelde instrumenten op elkaar aansluiten en hoe deze zijn toegepast bij het bepalen van de arbeidsmarktperspectieven van opleidingen en beroepen, zoals die worden weergegeven in het meer breed toegankelijke tweejaarlijks uit te brengen rapport. 


\subsection{Het programma $1989 / 1990$}

Het onderzoekprogramma bestaat zoals gezegd uit twee delen. Deel A betreft de projecten die in het kader van het meerjarige-project onderwijs en arbeidsmarkt worden uitgevoerd. Deel B betreft het overige onderzoek van het ROA. Alle projecten zijn genummerd. Elk nummer bestaat uit twee getallen. Het eerste getal geeft het jaar aan waarin met het project wordt begonnen, het tweede getal is een volgnummer, dat wordt voorafgegaan door de letter $A$ of $B$, afhankelijk van het programmadeel waaronder het desbetreffende project valt. De projecten die ook reeds voorkwamen in het vorige onderzoekprogramma hebben hun projectnummer behouden. De projectnummers die zijn overgeslagen betreffen reeds afgeronde projecten, of projecten waarvan vooralsnog wordt afgezien (zie paragraaf 4.2 ).

In principe wordt elk project afgesloten met een rapport of werkdocument. Wanneer dat echter doelmatig is, zullen de projectverslagen worden gecombineerd in één publikatie.

\section{Deel_A: Het informatiesysteem onderwijs-arbeidsmarkt}

Het programmadeel dat betrekking heeft op 1990, heeft zoals reeds opgemerkt, een voorlopig karakter en zal begin 1990 worden bijgesteld en aangevuld.

88/A1. Ontwikkeling van een verklarend model voor het prognosticeren van de arbeidsduur naar beroep en sector.

Afronding: zomer 1989.

88/A4. Ontwikkeling en schatting van opleidingenverdeelmodellen van de werkgelegenheid naar beroep en sector (omschrijving gewijzigd). Afronding: najaar 1989.

89/A2. Inpassing aanvullende en nieuwe databestanden in het statistisch basisbestand van het ROA. Doorlopende activiteit.

89/A4. Herschatting en verbetering van de ontwikkelde modellen (beroepen, opleidingen, vervangingsbehoefte en onderwijsuitstroom) en opstelling 
van nieuwe middellange-termijnprognoses. Uitbrengen van een breed toegankelijk rapport met de resultaten van deze prognoses en een rapport met een wetenschappelijke verantwoording.

Afronding: zomer 1990.

89/A5. Inventarisatie beschikbare databestanden en deelname aan coördinerende werkzaamheden van de interdepartementale commissie Onderwijs-Arbeidsmarkt Prognoses (commissie OAP)

Doorlopende activiteit.

89/A6. Empirische invulling van de nieuwe, aanvullende, indicatoren met betrekking tot beroepen en opleidingen.

Afronding: winter 1989/1990.

89/A7. Empirische verkenningen met betrekking tot de relatie tussen arbeidsmarktinformatie en opleidingskeuze en de dynamische effecten hiervan op de arbeidsmarkt.

Afronding: najaar 1989.

89/A8. Literatuurstudie naar schattingstechnieken voor verdeelmodellen, waarbij rekening wordt gehouden met de onderlinge afhankelijkheid van aandelen en het probleem van lege cellen in de datamatrix. Afronding: winter $1989 / 1990$.

90/A1. Internationale contacten met ontwikkelaars van gelijksoortige prognosemodellen als door het ROA worden gebruikt, mede ten behoeve van een voorgenomen werkconferentie.

Doorlopende activiteit.

90/A2. Verkenning van de mogelijkheden om het informatiesysteem onderwijsarbeidsmarkt te regionaliseren.

Afronding: zomer 1990.

90/A3. Inventarisatie van indicatoren voor technologische veranderingen en het ontwikkelen van modellen waarin de relatie tussen deze indicatoren en de beroepenstructuur van sectoren en de opleidingenstructuur van beroepen tot uitdrukking wordt gebracht.

Afronding: najaar 1990. 
Deel_B: Overige onderzoekprojecten

88/B1. Het traceren van de directe gevolgen van de technologische veranderingen in het bankwezen voor de werkgelegenheid, de beroepenstructuur en de opleidingsbehoefte. Het onderzoek wordt uitgevoerd in het kader van het OECD/CERI-project "Technological Change and Human Resources in the Service Sector." Het project wordt binnen de economische faculteit van de Rijksuniversiteit Limburg gezamenlijk uitgevoerd door de vakgroepen Algemene Economie, Kwantitatieve Economie en het ROA. Opdrachtgever: Ministerie van Onderwijs en Wetenschappen. Afronding: voorjaar 1989.

88/B2. Het verstrekken van gegevens over de arbeidsmarktperspectieven van opleidingen ten behoeve van de arbeidsmarktmodule van het geautomatiseerde systeem voor studie- en beroepskeuze I-See!. Opdrachtgever: Ministerie van Sociale Zaken en Werkgelegenheid. Afronding: Najaar 1989.

88/B3. Het onderzoeken van de arbeidsmarktpositie van LTS-leerlingen en de rol die arbeidsmarktfactoren spelen bij de keuze van de vakrichting. Het onderzoek wordt uitgevoerd in de vorm van een stageprogramma bij een LTS.

Doorlopend project.

88/B4. Het onderzoeken van de betekenis van de aard en het tijdpatroon van de beschikbare arbeidsmarktinformatie voor de keuzen binnen het onderwijs en voor de allocatie op en de dynamiek van de arbeidsmarkt. Financiering: AlO-plaats uit facultaire pool.

Afronding: zomer 1992.

88/B5. Pilot-onderzoek naar de mogelijkheden voor "follow-up" onderzoek onder de afgestudeerden in de gezondheidswetenschappen. In deze studie wordt gezocht naar de meest doelmatige organisatievorm, onderzoekmethode en meetinstrumenten om data met betrekking tot de arbeidsmarktpositie van afgestudeerde academici te verzamelen. Opdrachtgever: Ministerie van Onderwijs en Wetenschappen. Afronding: juni 1989. 
88/B6. Landelijke coördinatie van het project RUBS. Het pilot-project "Registratie Uitstroom en Bestemming van Schoolverlaters (RUBS)" heeft als doel het ontwikkelen van een landelijk bruikbaar meetinstrument ten behoeve van de registratie van de uitstroom van schoolverlaters en hun positie op de arbeidsmarkt. Daarnaast moet een model voor de gegevensopslag en verwerking worden ontwikkeld en een voorstel worden gedaan voor landelijke en regionale vervolgprojecten. Opdrachtgever: Ministerie van Sociale Zaken en Werkgelegenheid.

Afronding: januari 1990.

88/B7. Uitstroomonderzoek MBO Midden-Limburg. Dit project betreft een enquête onder uitstromers van het MBO te Roermond. Het onderzoek strekt zich uit over de gediplomeerde uitstroom in de jaren 1986 en 1987 van de MTS, MEAO, MMO-Commercieel en ter vergelijking één afdeling van het KMBO. Getracht wordt een beeld te schetsen van de "kwalitatieve aansluiting" van deze schoolverlaters op de arbeidsmarkt. De enquête sluit aan bij de nationale instrumentontwikkeling en classificaties in het kader van het project Registratie Uitstroom en Bestemming van Schoolverlaters (RUBS).

Opdrachtgever: Contactcentrum Onderwijs Arbeid (COA) Midden-Limburg. Afronding: mei 1989.

88/B8. Ontwikkeling informatiesysteem onderwijs-arbeidsmarkt, voor de haven van Rotterdam. Dit project betreft de ontwikkeling van een informatiesysteem onderwijs-arbeidsmarkt voor de haven van Rotterdam, dat een representatief beeld verschaft van de actuele arbeidsmarktsituatie en in het bijzonder ook van de perspectieven voor de middellange termijn ten aanzien van de aansluiting onderwijs-arbeidsmarkt. Dit informatiesysteem moet resulteren in een inzichtelijk en praktisch hanteerbaar instrument voor de beleidsbepaling ten aanzien van de kwantitatieve en kwalitatieve aansluiting van het onderwijs op de arbeidsmarkt. Er wordt een gefaseerde aanpak gevolgd. Thans wordt een inventariserend vooronderzoek uitgevoerd.

Opdrachtgever: Havenbedrijf der Gemeente Rotterdam Afronding vooronderzoek: mei 1989

89/B1. Onderzoek naar de uitstroom van studenten van de Rijksuniversiteit Limburg $(R L)$. Het onderzoek betreft de ontwikkeling van een systeem 
voor "follow-up" onderzoek onder afgestudeerden van de RL. Doel van het op te zetten systeem is het systematisch en periodiek beschikbaar komen van informatie over de kansen op de arbeidsmarkt van afgestudeerden en het functioneren van alumni in de beroepspraktijk. Opdrachtgever: College van Bestuur van de RL. Afronding: december 1990.

89/B2. Inventarisatie van technologie-indicatoren met betrekking tot scholing en arbeid. Bij dit project worden indicatoren gekwantificeerd die een beeld geven van de mate waarin het (gevolgde) onderwijs een goede maatschappelijke voedingsbodem biedt voor de diffusie van technologische vernieuwingen. Bruikbare indicatoren worden geselecteerd op basis van realiseerbaarheid, internationale vergelijkbaarheid en continuiteit. Van de indicatoren zullen tijdreeksen worden geconstrueerd vanaf 1980.

Opdrachtgever: Ministerie van Economische Zaken. Afronding: september 1989.

89/B3. Onderzoek naar de relatie tussen beroepskwalificaties en functies. Het project betreft de eerste fase van een onderzoek naar de wisse1werking tussen beroepskwalificaties en functie-inhouden. In een beschrijvende analyse zal worden gekeken naar de verschuivingen die in de jaren ' 80 zijn opgetreden in de functiestructuur. Ook wordt ingegaan op de relatie tussen deze verschuivingen, de mobiliteitsprocessen die zich op de arbeidsmarkt hebben voorgedaan en de mate waarin deze mobiliteit is gepaard gegaan met om-, her- en bijscholing.

Opdrachtgever: Organisatie voor Strategisch Arbeidsmarktonderzoek. Afronding eerste fase: januari 1990. 
BIJLAGE 1

PUBLIKATIES/PUBLICATIONS ROA

Rapporten/Reports:

ROA-R-1986/1 J.A.M. Heijke, Het Researchcentrum voor Onderwijs en Arbe idsmarkt.

ROA-R-1986/1E J.A.M. Heijke, The Research Centre for Education and Labour Market.

ROA-R-1987/1 A. de Grip, J.A.M. Heijke en L.A. Vos, Inventariserend onderzoek arbeidsmarktmodule I-SEE project.

ROA-R-1987/2 Naar een informatiesysteem onderwijs-arbeidsmarkt, onderzoekprogramma 1987/1988.

ROA-R-1987/3 A. de Grip, J.A.M. Heijke, R.J.P. Dekker, L.F.M. Groot en L.A. Vos, De arbeidsmarktperspectieven van studierichtingen in het wetenschappelijk onderwijs, Arbeidsmarktmodule I-SEE project.

ROA-R-1988/1 Naar een informatiesysteem onderwijs-arbeidsmarkt, onderzoekprogramma 1988/1989.

ROA-R-1988/2 A. de Grip, J.A.M., Heijke, J.W. van Dam, R.J.P. Dekker, M.H. Wieling, Aanvulling arbeidsmarktmodule I-SEE project (wetenschappelijk onderwijs).

LIB-R-89/002 P.J.M. Diederen, A. de Grip, L.F.M.Groot, J.A.M. Heijke, R.P.M. Kemp, J. Muysken, G.R. de Wit, Technological change, employment and skill formation in Dutch banking.

LIB-R-89/003 P.J.M. Diederen, A. de Grip, L.F.M. Groot, J.A.M. Heijke, R.P.M. Kemp, J. Muysken, G.R. de Wit, Technological change, employment and skill formation in Dutch retail.

LIB-R-89/004 P.J.M. Diederen, A. de Grip, L.F.M. Groot, J.A.M. Heijke, R.P.M. Kemp, J. Muysken, G.R. de Wit, Technological change and human resources in the service sector: the case of the Netherlands.

Werkdocumenten/Working papers:

ROA-W-1987/1

A. de Grip, J.A.M. Heijke, R.J.P. Dekker en L.F.M. Groot, De arbeidsmark naar beroep in 1992 en de positie van academici daarbinnen.

ROA-W-1987/1E

A. de Grip, J.A.M. Heijke, R.J.P. Dekker en L.F.M. Groot, Labour Market Prospects for Occupations and Academic Studies in 1992. 
ROA-W-1987/2E A. de Grip, L.F.M. Groot and J.A.M. Heijke, Clustering
Occupational Classes by Educational Structure.

ROA-W-1988/1 A. de Grip, J.A.M. Heijke, Arbeidsmarktindicatoren: een inventarisatie.

ROA-W-1988/1E A. de Grip, J.A.M. Heijke, Labour Market Indicators: an inventory.

ROA-W-1988/2 R.J.P. Dekker, A. de Grip, J.A.M. Heijke, Een verklaring van de beroepenstructuur van bedrijfstakken.

ROA-W-1988/2E R.J.P. Dekker, A. de Grip, J.A.M. Heijke, An explanation of the occupational structure of branches of industry.

ROA-W-1988/3 J.W. van Dam, A. de Grip, J.A.M. Heijke, Op zoek naar informatiebronnen over de arbeidsmarktpositie van academici.

ROA-W-1989/1E L. Borghans, Information and the choice for schooling.

Herdrukken/Reprints:

$n r \cdot 1$

A. de Grip, Causes of Labour Supply and Demand Mismatches in the Dutch Building Trades, in: De Economist, jrg. 135, $\mathrm{nr}$. 2, 1987, pp. 182-200.

$n r \cdot 2$

J.A.M. Heijke, The Labour Market Position of Migrants in Selected European Receiving Countries, in: The Future of Migration, OECD, Paris, pp. 170-209.

$n r \cdot 3$

J.A.M. Heijke, Internationale migratie en bevolkingsstructuur, in: Demografische veranderingen en economische ontwikkelingen. Preadviezen aan de Koninklijke Vereniging voor de Staathuishoudkunde 1987, H.E. Stenfert Kroese B.V., Leiden/Antwerpen, 1987, pp. 125-156.

$n r \cdot 4$

A. de Grip, Winnaars en Verliezers op de arbeidsmarkt 1981-1985 in: Tijdschrift voor Arbeidsvraagstukken, jrg. 3, nr. 4, 1987 pp. 61-69.

$n r \cdot 5$

J.A.M. Heijke, Arbeidsmarktinformatie voor studie en beroepskeuze, in: Dekanoloog, congresbundel, jrg. 25, nr. 1,1988 , pp. 20-22 en 13-14.

$n r \cdot 6$

J.A.M. Heijke, Arbeidsmarktinformatie en de keuze van studie en beroep, in: Dekanoloog, jaarcongres 1988, jrg. 25, nr. 5/6, pp. 155-160.

$n r \cdot 7$

A. de Grip. J.A.M. Heijke, R.J.P. Dekker, L.F.M. Groot, "De arbeidsmarkt naar beroep in 1992" en " Arbeidsmarktperspectieven van universitaire studierichtingen", in: Economisch Statistische Berichten, 29 juni en 6 juli 1988, 73 e jaargang, nrs. 3662 en 3663. 
$n r .8$

L.F.M. Groot, J.J. Schippers, J.J. Siegers, The effect of interruptions and part-time work on women's wage rate: a test of the variable-intensity model, in: De Economist, $136 \mathrm{nr}$. 2, $1988 \mathrm{pp} .220-238$.

\section{Overige publikaties medewerkers ROA:}

A. de Grip, Onderwijs en arbeidsmarkt: Scholingsdiscrepanties, proefschrift Vrije Universiteit, VU- Uitgeverij, Amsterdam, 1987.

A. de Grip, Werkgroep Functie-ordening van het Nederlands Genootschap voor informatica, Functies in de informatica, typering, plaats, functievereisten, loopbaanmogelijkheden, boekbespreking in: Tijdschrift voor Arbeidsvraagstukken, jrg. 3, nr. 2, 1987, pp. 91-92.

A. de Grip, Arbeidsmarkt als arena, boekbespreking in: Intermediair, jrg. 23, nr. 33, 1987, pp. 57-59.

L.A. Vos, De invloed van arbeidsmarktfactoren op de studiekeuze, doctoraal scriptie Vrije Universiteit, Maastricht, 1987.

F.H.H.C. Stijnen, M.H. Wieling, Arbeidsmarktverwachting en arbeidsmarktpositie van LTS-ers, stage-onderzoek in opdracht van COA-Limburg, Maastricht, 1988.

A. de Grip, Scholing en werk: Een analyse van de scholingsproblemen op de arbeidsmarkt en het arbeidsmarktbeleid, SMO-boek, 's-Gravenhage, 1988.

A. de Grip, Commentaar op de methodiek ter berekening van de gewenste instroom van studenten tweedegraads lerarenopleiding algemene vakken, Maastricht, 1989, (in opdracht van het Ministerie van Onderwijs en Wetenschappen).

A. de Grip, The Economics of Overeducation: A comment, in: Economics of Education Review, 1989, pp. 205-207. 
PERSONELE SAMENSTELLING ROA

Directeur : prof.dr. J.A.M. Heijke

$\begin{array}{ll}\text { Hoofdonderzoeker } & : \text { dr. A. de Grip } \\ \text { Onderzoekers } & \\ & \text { : } \\ & \text { drs. L.B.J. Borghans } \\ & \text { drs. J.W. van Dam } \\ & \text { drs. R.J.P. Dekker } \\ & \text { drs. L.F.M. Groot } \\ & \text { drs. W.J. Nusselder } \\ & \text { drs. H.M.M. Peeters } \\ & \text { drs. G.W.M. Ramaekers } \\ & \text { drs. E.J.T.A. Willems }\end{array}$

Student-assistenten: P.J.E. van de Loo

M.A. Mortier

J.J. Smorenburg

M.H. Wieling

J.A. Ie

Secretariaat : V.N.H.H. Lonissen-Moonen

: L.M.S. Romans

: J.M.J.A. Pisters

Adres

: Researchcentrum voor Onderwijs en Arbeidsmarkt Faculteit der Economische Wetenschappen, Rijksuniversiteit Limburg Tongersestraat 53, kamer 2019 Postbus 616

6200 MD Maastricht

telefoon: 043-888120/370

telefax : 043-252195 
$\underline{\text { BIJLAGE } 3}$

SAMENSTELLING BEGELEIDINGSCOMMISSIE VAN DE MEERJARIGE ONDERZOEKSOPDRACHT VAN HET MINISTERIE VAN ONDERWIJS EN WETENSCHAPPEN

drs. J. van den Bandt-Ste1

dr. B. Compayen

drs. N.J. Dersjant

drs. J. Geleedst

drs. M. Wegerif

prof. dr. A.M.L. van Wieringen (voorzitter)

dr. F.J.H. Don
Ministerie van Economische Zaken (ATB/I\&0)

Vrije Universiteit (FdEW), Amsterdam

Ministerie van Onderwijs en Wetenschappen (VO/VB)

Ministerie van Onderwijs en Wetenschappen (VO/VB)

Ministerie van Sociale Zaken en Werkgelegenheid (ARBVO)

Universiteit van Amsterdam (vakgroep Algemene en Vergelijkende Onderwijskunde)

Centraal Planbureau 


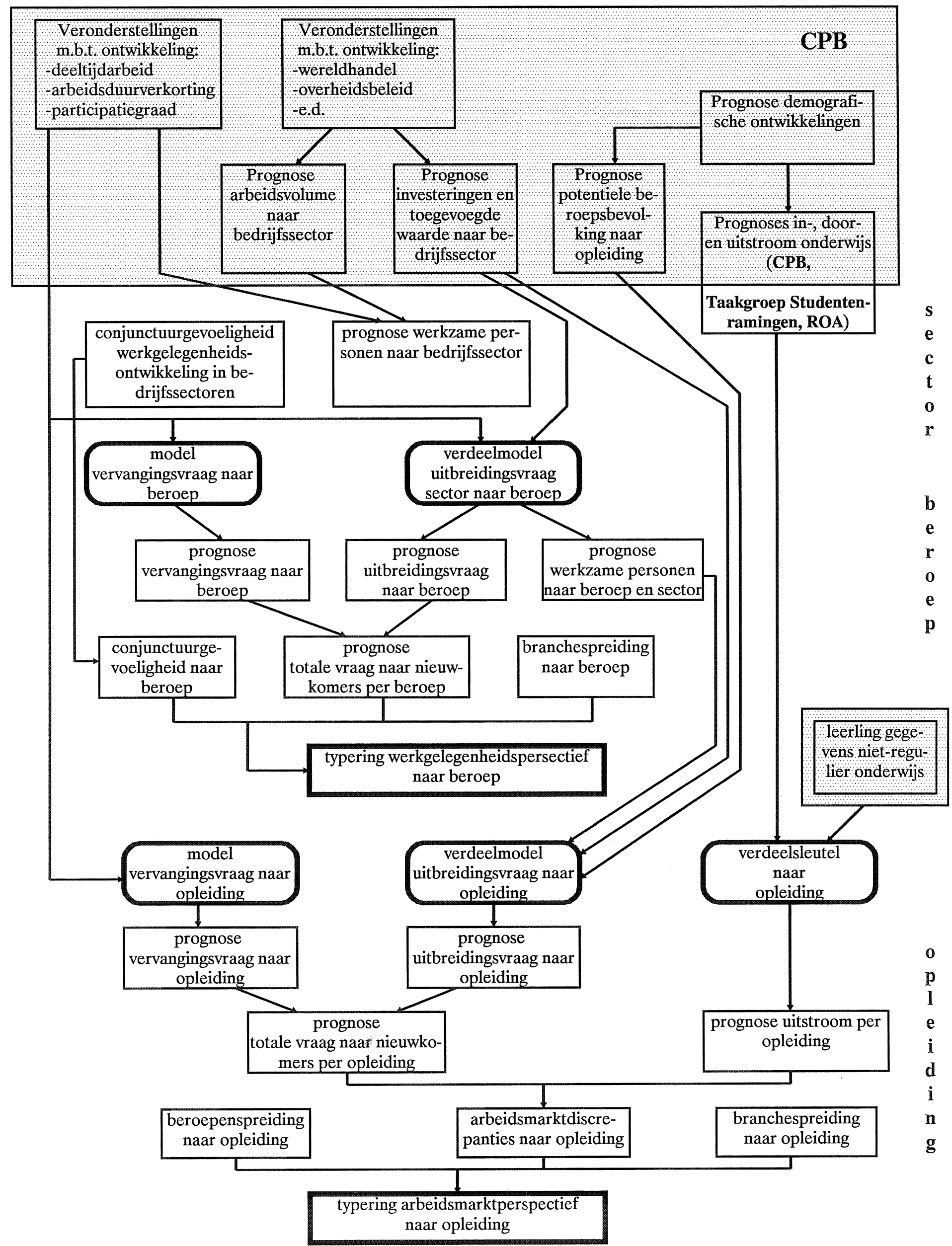




\section{Schema 1: De positie van het ROA}

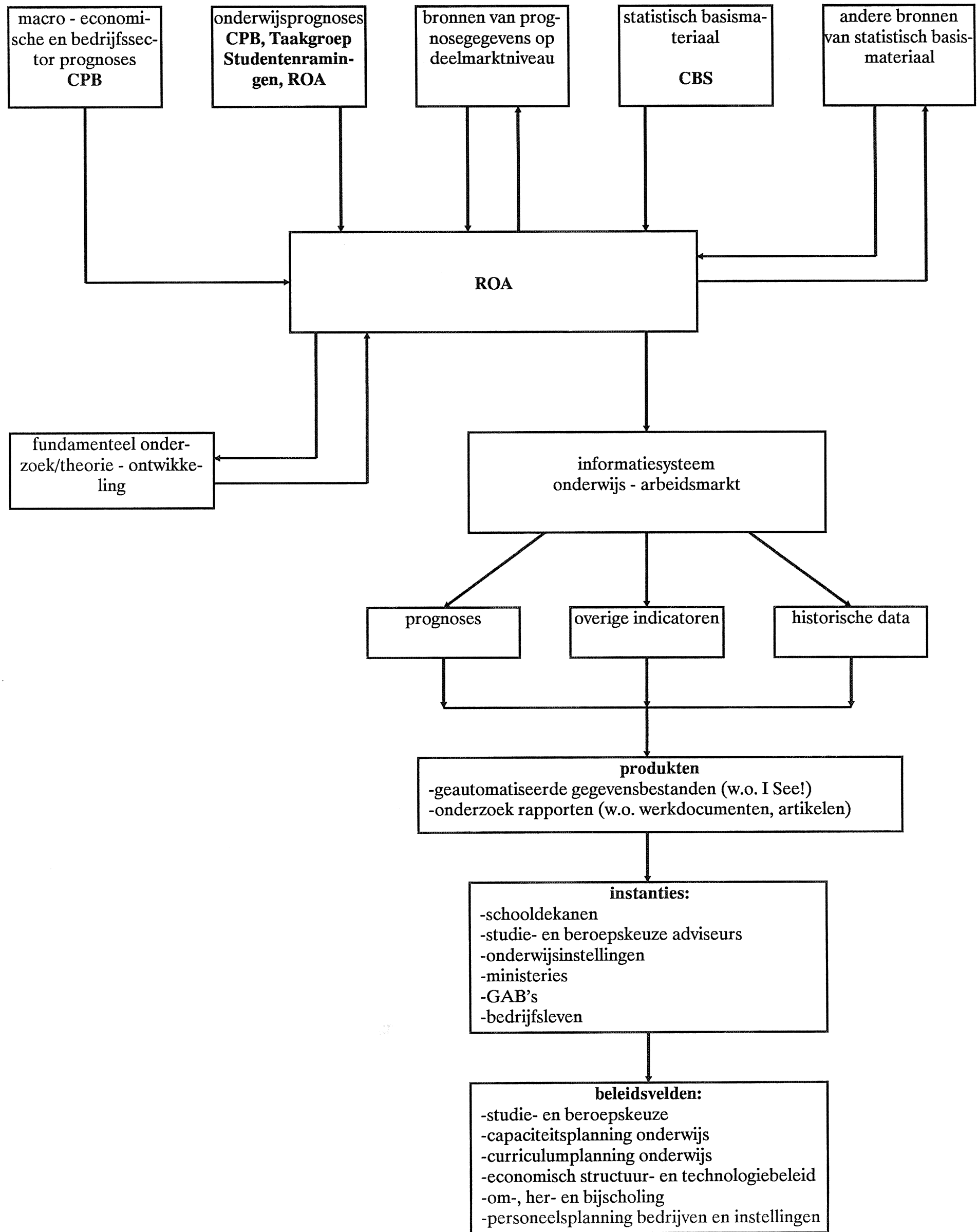

